density greater than a certain critical value, the behaviour is generally similar to that of the incompressible fluid, but that for lower densities equatorial break-up, by ejection of matter from the equator, will occur. These results were applied to the evolution of the solar system, binary stars and spiral nebulæ in an essay that was awarded the Adams Prize in 1916. The conception of gravitional instability as a cause of the separation of primitive material was due to Jeans. In his important investigations in stellar dynamics, the methods that he had developed for the kinetic theory of gases were applied to the stars.

IN recent years, Jeans has written a number of popular books on astronomy and physics which have had a world-wide circulation and have done much to create an interest in the more recent developments in these branches of science. Jeans served as secretary of the Royal Society from 1919 until 1929, and as president of the Royal Astronomical Society from 1925 until 1927. He received a Royal Medal of the Royal Society in 1919 and the Gold Medal of the Royal Astronomical Society in 1922. He was president of the British Association in 1934, and president of the Indian Science Congress at its jubilee meeting in 1938 .

\section{New Year Honours}

THE following names of men of science and others associated with scientific work also appear in the New Year Honours list: Baronet: Hon. Surgeon Commander J. D. Pollock, for benefactions and services to education. G.C.M.G.: Lord Hailey, director of the African Research Survey. G.C.V.O. : Sir John Reith. G.B.E.: Sir Frank Smith, Secretary of the Department of Scientific and Industrial Research, lately secretary of the Royal Society. K.C.M.G.: Sir Algernon Aspinall, lately secretary to the West India Committee. Knights : The Hon. Walter Gordon Duncan, president of the Royal Agricultural and Horticultural Society, South Australia; Prof. W. W. Jameson, dean and professor of public health, London School of Hygiene and Tropical Medicine; Prof. R. Robinson, Waynflete professor of chemistry in the University of Oxford ; Mr. Will Spens, master of Corpus Christi College, Cambridge ; Prof. R. G. Stapledon, professor of agricultural botany, University College of Wales, and director of the Welsh Plant Breeding Station, Aberystwyth. C.B. ' Mr. A. T. A. Dobson, fisheries secretary, Ministry of Agriculture and Fisheries. C.M.G. : Mr. J. N. Oliphant, director of the Imperial Forestry Institute, Oxford. C.I.E. : Dr. W. Burns, agricultural expert to the Government of India in the Imperial Council of Agricultural Research Department ; Lieut.-Colonel G. Covell, director of the Malaria Survey of India; Mr. A. C. Hiley, chief conservator of forests, Bombay; Mr. H. B. Dunnicliff, chief chemist, Central Revenues Chemical Service, and principal of the Government College, Lahore; Lieut.-Colonel E. W. O'G. Kirwan, professor of ophthalmic surgery, Medical College, Calcutta, Bengal. C.B.E. : Mr. W. F. Brown, chief mineral adviser to the Commissioners of Crown Lands, member of the board of governors of the Imperial Institute and of the Institute's Advisory Council on Minerals; Dr. A. S. Griffith, bacteriologist, Medical Research Council; Mr. R. P. Nicholson, lately secretary of the Royal African Society; Mr. F. C. Starling, assistant secretary and director of the Petroleum Department, Mines Department.

O.B.E. : Prof. W. F. Agar, professor of zoology, University of Melbourne; Dr. H. R. Angell, senior pathologist of plant industry, Council for Scientific and Industrial Research, Commonwealth of Australia; Lieut.-Colonel K. R. Krishnaswami Ayyangar, lately director of the Pasteur Institute of Southern India, Coonoor; Mr. B. E. Frayling, chief inspector of mines, Tanganyika Territory; Mr. P. A. Godwin, director of surveys and lands, Sierra Leone; Mr. D. K. S. Grant, conservator of forests, Tanganyika Territory ; Prof. C. J. Hawkes, professor of engineering, King's College, Newcastle, member of the Departmental Committee on the Examination of Engineers in the Mercantile Marine, 1937; Mr. W. F. Higgins, secretary of the National Physical Laboratory, Department of Scientific and Industrial Research; Miss Hilda Matheson, secretary to the African Research Survey; Mr. T. Rowatt, director of the Royal Scottish Museum; Mr. J. E. A. Wolryche-Whitmore, for services to agriculture in Kenya. M.B.E. : Mr. D. O. Drummond, deputy conservator of forests, United Provinces, India; Mr. R. T. M. Hayter, assistant director of the School of Tropical Medicine and resident medical officer, Carmichael Hospital, Calcutta, Bengal ; Mr. O. H. C. Shelswell, lately personal assistant to the chief conservator of forests, Madras.

\section{Captain B. S. Cohen, O.B.E.}

Captain Bertram S. Cohen, who retired from the post of staff engineer in charge of the Post Office Research Station at Dollis Hill, London, at the end of December, has been for forty years improving instruments and developing methods used in telephony. He joined the National Telephone Co. in 1896, the year in which the Post Office bought the long-distance telephone lines throughout the United Kingdom. As early as 1900, when Sir Oliver Lodge demonstrated his hornless loudspeaker before the Institution of Electrical Engineers, Cohen was one of the first to recognize the clearness of the articulation of the device, the faithful reproduction of radio telephony greatly impressing him. In conjunction with G. M. Shepherd he did excellent work in applying some of Heaviside's work to long-distance transmission over telephone lines. With impressive thoroughness, they evaluated the solutions of the very lengthy and difficult equations, sometimes involving inverse hyperbolic functions, which were continually arising in their experimental work. Cohen contributed a paper to the Physical Society in which he discussed the alterations in the everyday solutions due to the fact that the 'constants', such as the resistance, in some of the differential equations were really variables, and the solutions consisted of terms having 